\title{
K. Ratajczak, Szkolnictwo w Wielkopolsce na tle sqasiadów w okresie średniowiecza, Wydawnictwo Naukowe UAM, Poznań 2017, ss. 368
}

Polska historiografia w 2017 r. wzbogaciła się o długo wyczekiwane opracowanie dziejów szkolnictwa średniowiecznego w Wielkopolsce pt. Szkolnictwo w Wielkopolsce na tle sasiadów w okresie średniowiecza. Jego autorem jest prof. UAM dr hab. Krzysztof Ratajczak, autor wielu prac poświęconych historii wychowania i kulturze średniowiecznej. Książka składa się z wykazu skrótów, wstępu, pięciu rozdziałów w układzie problemowo-chronologicznym, zakończenia, aneksu, bibliografii, indeksu osobowego i nazw geograficznych oraz podsumowania w j. angielskim. Całość liczy 368 stron.

Zasadniczym przedmiotem prezentowanej książki jest omówienie dziejów szkolnictwa średniowiecznej Wielkopolski na tle sąsiednich regionów, ale też, na co warto zwrócić uwagę, ukazanie drogi recepcji prawnych i funkcjonalnych rozwiązań, wytworzonych w państwach chrześcijańskiej, łacińskiej Europy. Praca ta zasługuje na uwagę z kilku powodów. Najbardziej oczywistym wydaje się wypełnienie poważnego braku w polskiej historiografii. O wartości tej książki świadczą jednak poważne studia źródłoznawcze, rzetelnie przeprowadzone przez Autora i wnikliwa analiza zgromadzonego w trakcie kwerendy materiału źródłowego. Znaczącym atutem są też aneks oraz indeksy, sporządzone skrupulatnie i przy dużym nakładzie pracy, świadczące o rozumieniu potrzeb czytelnika i badacza.

Wielkopolska od początków historii Polski zawsze była regionem szczególnym, odgrywającym pierwszoplanową rolę. Dotyczy to takich aspektów, jak polityczny, gospodarczy, ale także i oświatowy, które, co ważne, wzajemnie się przenikały i warunkowały. To tutaj kształtowały się zręby państwowości Polski, tutaj instalował się po raz pierwszy Kościół katolicki wraz z zalążkami przyszłego systemu oświatowego. To w Wielkopolsce powstała pierwsza w Rzeczypospolitej szkoła średnia typu humanistycznego, a tutejsze szkoły wydziałowe i podwydziałowe przodowały w ocenach 
Komisji Edukacji Narodowej. Te edukacyjne osiągnięcia oczywiście możliwe były dzięki szkolnemu dziedzictwu średniowiecza. To z kolei funkcjonowało na fundamencie konkretnych rozwiązań prawnych i praktycznych, które są przedmiotem rozważań w pierwszym rozdziale książki.

Rozdział ten stanowi prolegomenę do właściwych rozważań, a omówiono w nim zagadnienia edukacyjnej działalności Kościoła, włączając w to kwestie ustawodawstwa szkolnego od III do XVI w. Autor rozpoczyna narrację od ukazania początków tej działalności - odnosząc się do wspomnianego ustawodawstwa, dzieł Ojców i Doktorów Kościoła oraz i obfitej literatury przedmiotu - po czym przechodzi do omówienia wybranych problemów. Wśród nich znajdziemy zagadnienia począwszy od kształcenia duchowieństwa, nauczania osób świeckich w szkołach kościelnych, programu nauczania, ustawodawstwa zakonnego, skończywszy na problematyce ustawodawstwa kościelnego w stosunku do uniwersytetów. O ile pierwsze cztery punkty stanowią dobre wprowadzenie do problematyki „wielkopolskiej”, o tyle w związku z tym, że na terenie Wielkopolski nie utworzono w średniowieczu uniwersytetu, można by się zastanowić nad zasadnością podejmowania tego ostatniego wątku. Świadczy on oczywiście o erudycji Autora, jednak odrywa uwagę czytelnika od głównego przedmiotu.

Podczas lektury omawianej książki warto poświęcić uwagę drugiemu rozdziałowi, który dzięki ukazaniu prawnych i organizacyjnych podstaw funkcjonowania kształtu i jakości edukacji w średniowiecznej Wielkopolsce pozwala czytelnikowi na ich zrozumienie. Zważywszy na fakt, że szkolnictwo ówczesne prowadzone było wyłącznie przez instytucje związane z Kościołem katolickim, związane było ono ściśle z normami tegoż Kościoła i jego możliwościami na różnych płaszczyznach. Autor podejmuje tu zagadnienia synodów legackich, prowincjonalnych, diecezjalnych czy zbiorów prawa kanonicznego, analizując ich wpływ na rozwój rodzimego prawodawstwa kościelnego. Uwagę poświęcono tutaj także ustawodawstwu zakonnemu polskiej prowincji kościelnej różnych zakonów. Nieco miejsca w książce zajmuje kwestia pośredniej recepcji kościelnego ustawodawstwa wraz z analizą problemu zagranicznych studiów polskich duchownych czy kolonizacji na prawie niemieckim i kontaktów z zachodem Europy.

Trzeci rozdział przynosi analizę szkolnictwa katedralnego i kolegiackiego na terenie Wielkopolski. Wydzielenie tych szkół i odrębne omówienie należy uznać za słuszne ze względu na ich specyfikę i inne cele funkcjonowania. Autor wnikliwie przygląda się początkom tych szkół, sięgając do najstarszych przekazów źródłowych, a następnie dokładnie omawiając szkoły katedralne gnieźnieńską i poznańską, z uwzględnieniem ewolucji programu nauczania, osób nauczających i uczniów. Następnie przybliża zagadnienie formowania się szkolnictwa kolegiackiego, podkreślając misję wspólnot kanonickich i oczekiwane od ich członków wykształcenie, rzutujące według Autora na kwestie szkolne. Sporo miejsca poświęca nauczycielom i uczniom, zwracając przy tym uwagę nie tylko na zagadnienia edukacyjne, ale i bytowe. Nie pomija też programu nauczania, inicjując zagadnienie uwagami metodologicznymi, a kończąc sformułowaniem celu funkcjonowania tych szkół - przygotowaniem mianowicie do formacji kapłańskiej 
i podjęcia studiów uniwersyteckich. Rozdział ten zwieńczony został omówieniem wykształcenia duchowieństwa oraz zagadnienia podstaw materialnych funkcjonowania szkół.

W kolejnym rozdziale analizie poddano problematykę szkół parafialnych w Wielkopolsce, prowadząc narrację od rekonstrukcji sieci parafialnej i ukazania ścisłego związku, który łączył szkołę z organizacją parafialną. Dokładniejsze omówienie specyfiki tych szkół ma miejsce w dalszej części, gdzie został zawarty podział na szkoły miejskie i wiejskie, co należy uznać za słuszne posunięcie, zważywszy na chronologię powstawania i wyjątkowość tych pierwszych. Autor skrupulatnie wylicza miejsca fundacji, podaje szacunki dotyczące liczby uczniów, wskazuje na stopień scholaryzacji ówczesnego społeczeństwa. Następnie omówiono pokrótce zagadnienie programu nauczania, wskazując na odmienność szkolnictwa miejskiego, w którym treści kształcenia były często uzależnione od decyzji władz miejskich i odpowiadały potrzebom mieszczaństwa. Nieco miejsca poświęcono uposażeniu i kwestiom materialnym, w dalszej części znajdziemy także informacje na temat nauczycieli, ich wykształcenia, nakładanych na nich obowiązków czy różnych współzależności w obrębie parafii. Nie pominięto także uczniów szkół parafialnych. Opisano tu chociażby znane z materiałów źródłowych przykłady uniwersyteckich immatrykulacji absolwentów wielkopolskich szkół parafialnych, wiek rozpoczynania edukacji, odbiegający od norm europejskich, czy problemy natury ekonomicznej. Na końcu rozdziału zamieszczono krótką notatkę na temat kształcenia dziewcząt w szkołach parafialnych, w której odniesiono się do analogii z innych obszarów i wskazano na dwa przykłady wykształconych kobiet w średniowiecznej Wielkopolsce: notariuszki i lekarki.

Przedmiotem ostatniego rozdziału jest szkolnictwo zakonne na terenie Wielkopolski. Wstęp do tej części stanowi opis sieci klasztorów na tym obszarze i omówienie znaczenia szkoły dla funkcjonowania konwentu i jej specyfiki w poszczególnych zgromadzeniach zakonnych. Ze względu na niedostateczną ilość materiałów źródłowych zagadnienie nauczycieli szkół zakonnych zostało omówione dość pobieżnie. Nieco lepiej przedstawia się to $\mathrm{w}$ odniesieniu do kolejnych zagadnień: nowicjatu, przygotowującego do dalszych nauk, szkoły konwentualnej, studiów uniwersyteckich absolwentów. Analizę zamyka zagadnienie szkolnictwa zewnętrznego, czyli otwarcia szkół zakonnych dla osób świeckich.

W zakończeniu książki zamieszczono syntetyczne podsumowanie najważniejszych ustaleń. Zakończenie to należy uznać za cenne, ponieważ zawarto tu pewne oceny opisywanych zjawisk, porównania do szkolnictwa z innych obszarów, np. Czech, i uwagi dotyczące stanu badań. Nie zabrakło tu też postulatów badawczych, przede wszystkim wskazujących na potrzebę badań o charakterze prozopograficznym i porównawczym.

Ważnym elementem opisywanej książki jest zamieszczony na końcu aneks. Stanowi on tabelaryczny wykaz wzmianek źródłowych o szkołach w Wielkopolsce. Zestawienie to uznać należy za cenny wkład Autora w badania nad tym tematem. Umożliwia zorientowanie się w istniejących przekazach źródłowych, obrazuje stan naszej wiedzy i z całą 
pewnością ułatwia kontynuację badań. W związku z tym, że tabela ta może stanowić narzędzie badawcze, warto w tym miejscu wskazać na pewne braki czy trudności, które mogą pojawić się w związku z nią.

Podane w aneksie nazwy miejscowości, które zresztą stanowią podstawę jego budowy, są trudne do weryfikacji z dzisiejszej perspektywy. Ponadto gdyby Autor podjął próbę identyfikacji albo podzielił się z czytelnikiem wynikiem takowego zabiegu - np. podając przynajmniej przybliżoną lokalizację - wówczas można by w znacznie większym stopniu czerpać korzyści z dobrodziejstwa wypracowanej tabeli i nie mieć wątpliwości co do zasadności policzenia danej miejscowości do Wielkopolski. Czy do tego spisu bowiem powinien trafić Biecz, który raczej kojarzy się z miejscowością w Małopolsce (chyba że mamy tutaj do czynienia z problemem natury edytorskiej - wiadomo, że edytory tekstu potrafią automatycznie przekształcać niektóre nazwy według swojego słownika...) albo Bielawa - na Śląsku (tu oczywiście można założyć, że chodzi o wieś krajeńską, obecnie w gminie Złotów, ale może jednak Bielawy z gminy Śmigiel? - obie w Wielkopolsce)? Trzeba zaznaczyć też, że w omawianym aneksie brakuje opisu metody wykorzystanej przy jego tworzeniu, nie znajdziemy go także we wstępie do pracy. Uwagę przykuwa również fakt, że Autor podaje dokładne dane bibliograficzne tylko w niektórych przypadkach. Co zaskakujące - w odniesieniu do tych samych źródeł czasem podano numer strony czy karty, a czasem nie. Warto by także uporządkować prezentowane dane i podawać je w ustalonym porządku. W większości przykładów wypisy ze źródeł podano w formie mianownikowej (np. rector scholae, minister scholae itp.), ale są i odstępstwa od tego. Dla przykładu nr 140: tutoris puerorum czy $\mathrm{nr} 332$ : domo vicarii et schola. Zmiana na formę tutor puerorum nie zmieniłaby przecież sensu. Estetykę zestawienia poprawiłoby także konsekwentne stosowanie wielkiej lub małej litery w kolejnych pozycjach. Oczywiście te ostatnie uwagi nie mają dużego znaczenia i nie umniejszają wartości aneksu.

Po tym pobieżnym przeglądzie treści książki wypada zwrócić uwagę na kilka istotnych kwestii. Autor już we wstępie do pracy sugeruje, że przeprowadzone przez niego badania mogą przyczynić się do rewizji ustaleń uważanych dotąd w literaturze za niepodważalne oraz rozprawienia się z pewnymi uogólnieniami i nieścisłościami (s. 9). Czy wywiązuje się z podjętego zobowiązania?

Podkreślić trzeba, że niezaprzeczalną zaletą omawianej książki jest znaczące uzupełnienie naszego stanu wiedzy na temat wielkopolskiej oświaty czasów średniowiecznych. Przeprowadzona przez Autora kwerenda, dzięki uwzględnieniu pomijanych we wcześniejszych badaniach osób związanych ze szkolnictwem, np. świadków w procesach, pozwoliła na dodanie do spisu nieznanych dotąd lokalizacji szkolnych.

Warto zauważyć, że we wstępie Autor zaznacza, że trzeba się zgodzić z tezą przestawioną przez Krzysztofa Ożoga, że istnienie znacznej liczby szkół parafialnych skutkowało alfabetyzacją społeczeństwa (s. 20). Zdaje się, że konstatacja taka, choć kusząca, jest nazbyt optymistyczną, przede wszystkim jeśli weźmiemy pod uwagę sprawę programu nauczania. Co najistotniejsze, stwierdzić trzeba, że nie jest on znany. A skądinąd 
wiemy, że częstym zwyczajem było ograniczanie się w takich szkołach do spraw wiary i śpiewu na potrzeby nabożeństw. W części takich szkół być może wcale nie uczono czytania. Oczekiwanej odpowiedzi nie przynosi także lektura dedykowanego podrozdziału, poświęconego programowi nauczania szkół parafialnych. Autor ogranicza się tutaj do ogólnikowych i utartych stwierdzeń, w kwestii alfabetyzacji społeczeństwa powołując się na jeden tekst źródłowy ze schyłku średniowiecza, z 1488 r. (s. 216), co oczywiście nie może być miarodajne dla całej epoki. Nie można też odnosić do wszystkich szkół parafialnych praktyki szkół miejskich, które ze względu na potrzeby społeczności miejskiej miały swój specyficzny charakter.

W odniesieniu do wielu zagadnień Autor zbiera i porządkuje zasób wiedzy gromadzony od wielu dekad i łączy go z własnymi odkryciami źródłowymi, co sprawia, że zagadnienie edukacji na terenie średniowiecznej Wielkopolski przedstawione jest w sposób dotąd najpełniejszy i z perspektywy historyczno-pedagogicznej. Warto podkreślić, że Autor rozumie zagadnienia edukacyjne i wykorzystuje to w swojej pracy, uwzględniając np. cel funkcjonowania poszczególnych rodzajów szkól, stosowane metody nauczania, program kształcenia, przygotowanie kadr nauczycielskich. Bez uwzględnienia tych aspektów opracowanie byłoby niepełne.

W książce nie uniknięto pewnych drobnych potknięć edytorskich czy językowych. W spisie treści dla przykładu w tytule pierwszego rozdziału widzimy „prologomena” zamiast „prolegomena”. Na s. 13 czytamy o „otworzeniu sieci parafialnej” (zamiast zapewne odtworzeniu). Ogólnie jednak trzeba przyznać, że korektę przeprowadzono wnikliwie i takich drobnych błędów jest niewiele, a książkę czyta się z przyjemnością.

Konkludując, należy stwierdzić, że książka Krzysztofa Ratajczaka to pozycja, na którą historycy czekali od dawna i która z pewnością wypełnia dotkliwy brak w historiografii średniowiecznej edukacji, dotyczący zwłaszcza obszaru Wielkopolski. Jest to praca ważna, gdyż z jednej strony traktuje o dziejach szkolnictwa z perspektywy historii wychowania, $\mathrm{z}$ drugiej natomiast korzysta $\mathrm{z}$ dobrego warsztatu historycznego $\mathrm{i}$ bazuje na solidnej podstawie źródłowej oraz bogatej literaturze przedmiotu. Zdecydowanie więc należy rekomendować jej lekturę i wykorzystanie w dalszych badaniach. 